\title{
Hybridization Array
}

National Cancer Institute

\section{Source}

National Cancer Institute. Hybridization Array. NCI Thesaurus. Code C18842.

A molecular biology device that utilizes a set of defined oligonucleotide probes,

recombinant clones, or other samples attached in a specific grid arrangement to a solid support for nucleic acid hybridization assays in gene mapping studies or in determining gene sequences, sequence variations, or gene expression patterns. 